KORINEK Beáta Zsófia

DOI: 10.15170/DIKE.2021.05.01.08

tanársegéd

PTE ÁJK

\title{
Mit üzen a múlt?
}

\section{Gondolatok a II. világháborút követő gyermekvédelmi reformtörekvésekről és a gyermekköztársaságokról}

"A squenvedés elkerülhetetlen és univerzális. A különbség abban áll, ahogyan a sz̨envedésre reagálunk."

E. E. Egert

\begin{abstract}
What Does the Past Say? Thoughts about Child Protection Reform Efforts and Children's Republics after World War II

One of the greatest global traumas of the 20th century was World War II. Millions of children have become abandoned. In this extreme life situation, professionals, responsible adults and reform educators felt it their job to embrace and save them. They worked to ensure that orphaned children could continue their lives without a family background. In my study, I present the importance of action instead of 'bystander effect' and the importance of 'becoming capable' and 'empowerment' instead of simple care for children in need through a couple of examples of socalled children's republics, primarily Father Flanagen's Boys Town and Gábor Szteblo's Gaudiopolis.
\end{abstract}

Keywords: children's republic, child protection, the best regards of the child, World War II, reform pedagogy, Boys Tows, Gaudiopolis

\section{A traumatizált gyermekek és az „irgalmas szamaritánus”}

A II. világháború időszakában Európában és Európán kívül is gyermekek tömegei váltak árvává vagy elhagyatottá. Sokan hónapokat töltöttek felnőtt felügyelet nélkül, a túlélésért küzdve. Az éhezés, a család elvesztése tragikus események, de a mindennapos szenvedés és félelem, a kiszámíthatatlanság, a halál látványa tovább mélyítette belső drámájukat. Ezeknek a gyerekeknek a társadalomba való visszaintegrálása óriási kihívást jelentett a világégés alatt és az azt követő években is. A trauma (egy a megszokottól, a hétköznapitól extrém módon eltérő esemény vagy történés), sajnos része az emberi életnek, a megfelelő traumafeldolgozás pedig olyan feladat, melynek sikeres 
megvalósulása a személyiség tovább fejlődését eredményezheti. A gyermek azonban erre - koránál és éretlenségénél fogva - segítség nélkül képtelen. ${ }^{1}$

Az 1989. november 20-i New York-i Gyermekjogi Egyezmény többek között ezekből a történelmi tapasztalatokból kiindulva külön cikkelyben foglalkozott a háborús (fegyveres) konfliktusban éló gyermekek védelmével és helyzetével. ${ }^{2}$ Hasonlóan fontos szempontnak bizonyult a gyermek családban történő nevelkedésének az elve, ${ }^{3}$ melynek a biztosítására azért kell a végsőkig törekedni, mert a gyermek fejlődése szempontjából rendkívül lényeges érdekről van szó. Bizonyos körülmények esetén sajnálatosan mégis az ellenkezőjére kerül sor: ha a gyermek nem hagyható a családja veszélyeztető közegében, épp az ő érdekében történik meg a családból történő kiemelése. Nem kell feltétlenül háborút megélnie egy gyermeknek ahhoz, hogy súlyosan traumatizálódjon, mert sok esetben a háború a négy fal között zajlik a családjában vagy a szúkebb környezetében. A bántalmazott gyermekek kezelése a háborút átéltekéhez hasonlóan nagy kihívást jelentett és nagy kihívás ma is a szakemberek számára. Ahhoz, hogy a traumák okozta sebek begyógyulhassanak és az egykori áldozatok megerősödött személyiséggel léphessenek be a felnőttkorba, megfelelő bánásmódra, illetve kezelésre van szükség: a bántott gyermeknek vissza kell nyernie a hitét a felnőttek irányába, valamint újra meg kell tanulnia bízni a külvilágban, és még inkább saját magában.

A II. világháború utáni évtizedek szociálpszichológiai kutatásai több szempontból is reagáltak a traumatizált gyermekek helyzetére. Egyrészt a felnőttek által asszisztált gyógyulási folyamatnak a megvalósulását azért hangsúlyozták, mert a cselekvés, a megsegítés elmaradása esetén rögzülhet a bántalmazott gyermekben, hogy nincs segítség, hogy nem érdemes cselekedni és hangot adni a nemtetszésének. A folyamat passzív elszenvedése hosszútávon az úgynevezett tanult tehetetlenség (learned belplessness) ${ }^{4}$ állapotához vezethet, amelyben a gyermek világa kiszámíthatatlanná válik, és elhiszi, hogy nincs hatással a saját életére, melytől fokozottan szenved.

Másrészt az úgynevezett bámészkodó hatás (bystander effect) kutatói, John Darley és Bibb Latané new yorki szociálpszichológusok azt vizsgálták, hogy egy traumát okozó esemény szemtanúinak feltételezett közönye mivel magyarázható. ${ }^{5}$ Számos kísérleti elrendezést alkalmazva jutottak például arra a következtetésre, hogy minél többen vannak jelen egy vészhelyzet során, minél több a „bámészkodó”, annál jobban megoszlik az egyéni felelősség érzése a szemtanúkban, és ezért csökken az egyén késztetése a beavatkozásra. Hasonló élethelyzetekben kulcsfontosságú, hogy minél többen vegyék észre a rendellenes történést, és valóban képesek legyenek jól értelmezni a tapasztalt cselekményeket, mégpedig lehetőleg annak, ami az valójában, vagyis vészhelyzetnek, másrészt az azt észlelők lehetőleg ne keressenek önigazolást a passzív viselkedésre („,magának

\footnotetext{
${ }^{1}$ EGERT, A döntés 257-268.

2 1991. évi LXIV. törvény a Gyermek jogairól szóló, New Yorkban, 1989. november 20-án kelt Egyezmény kihirdetéséről. 38. cikk 4. bek. „Az Egyezményben részes államok a fegyveres konfliktus esetén a polgári lakosság védelmét illetöen a nemzetközi bumanitárius jog értelmében reájuk háruló kötelezettségüknek megfelelöen megtesznek minden lehetó gyakorlati intézkedést a fegyveres konfliktus által érintett gyermekek védelemben és gondozásban részesitésére.” 39. cikk: „Az egyezményben részes államok megtesznek. minden alkalmas intézkedést arra, hogy az elhanyagolás, a kizsákmányolás és a durva bánásmód, a kiñás vagy a kegyetlen, embertelen vagy megalázó büntetések, vagy bánásmód bármely más formájának, illetöleg a fegyveres konfliktusnak áldozatává vált bármely gyermek testi és szellemi rehabilitációját és a társadalomba való beillesqkedését megkönnyitsék. Ennek a rehabilitációnak és a társadalomba való beilleszkedésnek a gyermek egészségét, önbecsülését és emberi méltóságát fejlesżö körülmények közö̈t kell történnie.”

${ }^{3}$ Lásd 2013. évi V. tv. 4:2. \ [A gyermek érdekének védelme].

${ }^{4}$ EGERT, Az ajándék 12 életmentő lecke 13., ABRAHAMSON - SELIGMAN - TEASDALE, Learned helplessness in humans 49-74. és Hiroto, Locus of control and learned helplessness 187-193.

${ }^{5}$ DARLEY - LATANÉ, Bystander intervention in emergencies 377-383.
} 
kereste a bajt”, „nem az én dolgom a segítség” stb.). Megnő a segítségnyújtás valószínűsége akkor is, ha a bajbajutott egyértelmúen csak egy személyre számíthat, esetleg közvetlenül adott személy segítségét kéri.

A kutatók megállapították, hogy az ilyen helyzetekben két ellentétes társadalmi szabály feszül egymásnak: a názáreti Jéqus hegyi beszédéből ${ }^{6}$ ismert felhívás a segítségnyújtás fontosságára és annak mikéntjére, másrészt a társadalmi megfelelés igénye a többség követésére, ami sok esetben a passzivitást jelenti. ${ }^{7} \mathrm{Az}$ alábbi tanulmányban az úgynevezett gyermekköztársaságok példáján keresztül azt vizsgálom, hogy a ,irgalmas szamaritánusok” mit tettek a II. világháború éveiben és azt követően annak érdekében, hogy ne a tanult tehetetlenség jelensége uralkodjon el a traumatizált gyermekek sokaságán, hanem egészséges felnőttekké tudjanak válni. Az a kérdés, hogy van-e létjogosultságuk a gyermekköztársaságoknak a 21. században, külön tanulmány tárgyát képezi.

\section{Gyermekköztársaság vagy gyermekváros?}

A gyermekköztársaságok olyan minidemokráciák, amelyekben a veszélyeztetett, különböző okoknál fogva család nélkül kallódó gyerekek alapvető - normális körülmények között a család, az iskola, a megtartó társadalmi közösség szocializáló tevékenységéből elsajátítható - értékeket kapnak, önállóságra nevelik őket, szeretetteljes, családot pótolni igyekvő közösségben terelgetik őket egy sikeresebb felnőttkor felé. Áttanulmányozva a háború okozta társadalmi krízisben született közösségek történetét, arra a megállapításra jutottam, hogy a kezdeményezések elindítói többnyire fiatal papok, tanárok voltak. Sokszor eszembe jutott Néri Szent Fülöp (Filippo Romolo Neri, 1515-1595) ${ }^{8}$ karizmatikus személyisége, aki nem kifejezetten háború miatt, hanem a társadalom nemtörődömsége okán vállalta magára az utcagyerekek felkarolását és tanítását. A gyermekek helyzete szempontjából nem lehet élesen elhatárolni a krízist, amit egy fegyveres konfliktus okoz, és azt a krízist, ami ott lappang egy olyan társadalomban, ahol a „jó szamaritánus” attitűd nagyrészt hiányzik a közösség tagjaiból.

A két világháború közötti években kibontakozó demokrácia-deficit az európai államok jelentős részében, majd a „Harmadik Birodalom” és az általa megszállt területek közjogi berendezkedése kifejezetten kedvezôtlen fundamentuma volt a demokratikus elveken múködő gyerekköztársaságoknak. Az 1939 szeptemberében elkezdődő hadi események következtében gyerekek tömegei jutottak árvaságra, súlyos test és lelki sérüléseket cipelve. Harcok, bombázások, halott emberek látványa... Magukra maradtak, harcoltak az életben maradásért, előfordult, hogy lopásra, rablásra kényszerültek a túlélésért. Csapatokba verődtek, bűnözô életmódot folytató felnőttektől tanultak és így kriminalizálódtak, vagy maguk is részt vettek a harcokban. Szélsőségesen realisztikus és sötét oldalát tanulták meg a világnak, amiben léteztek. Kívül felnőttként kellett viselkedniük a még éretlen személyiségükkel. A ,jószóra” egy idô után nem hallgattak, mert nem hittek benne. Ezekkel a kiskorú gyermekekkel nehezen lehetett bánni, hagyományos iskolába nem

\footnotetext{
${ }^{6}$ Máté 7:12 „Amit tehát szeretnétek, hogy az emberek veletek cselekedjenek, ti is ugyanaz̧ cselekedjétek, velïk, mert ez a törvény, és ezt tanitják a próféták."

${ }^{7}$ Konformitás. Asch-kísérlete. Lásd: Asch, Opinions and social pressure 318-324.

${ }^{8}$ BACCI, The life of Saint Philip Neri, https://archive.org/details/lifeofphilipneri01baccuoft/page/n397/mode/2up.
} 
voltak beilleszthetők, és hagyományos gyermekotthonban sem tudták kezelni elvadult, megsérült személyiségüket. A háború után alig maradt épen iskola, otthon, alig volt nevelő, pedagógus, és teljes volt a fejetlenség a felügyelet nélkül maradt gyermekek rendkívül magas száma miatt. A munkaerőhiányon és a háborút megélt, magukra maradt gyermekek sajátos állapotán túl több európai államban volt egy harmadik probléma is, mégpedig annak az ideológiai (át)nevelésnek a következménye, amely mély nyomot hagyott az emberekben, így a gyermekekben is. ${ }^{9}$

Ebben a nehéz helyzetben olyan reformpedagógiai, nevelési módszerek bizonyultak leginkább múködőképesnek, amelyek képessé tették a gyerekeket az önállósodásra és a munkavégzésre. Ezért a gyermekköztársaságokban többnyire olyan múhelyek múködtek, melyekben a gyerekeket egyrészt képezték, másrészt sok esetben saját ellátásukhoz is hozzájárultak a munkájukkal. A tanult tehetetlenség jelenségével szemben nagy jelentősége volt a munkának, illetve annak, hogy a gyermekek hasznosnak érezhették magukat ezekben az intézményekben: az aktív tevékenykedés traumaoldó hatására kétségen kívül beigazolódott. Az önkormányzás elvei alapján múködő köztársaságok a munkára nevelésen, az önállósodáson túl a közösségben való együttmúködésre, a másikra való odafigyelésre is neveltek. Elsajátították a demokrácia alapelveit is azzal, hogy szavazatukkal felnőtt felügyelet mellett, de maguk dönthettek elöljáróikról, szabályaikról, közösségük működéséről. Lényegében megtanulhatták, hogy milyen a világ békeidőben és milyen fontos ennek a békének a fenntartása, amibe nekik is beleszólásuk van.

A gyermekköztársaságokhoz hasonló, de a gyermekközösség önkormányzatiságát nem hangsúlyozó szervezeti modell a II. világháború utáni szovjetblokk országaiban a gyermekváros, amelyet a neveléstörténeti szakirodalom az állami gyermekvédelmi rendszer egy elemeként definiált. A gyermekvárosok hazánkban olyan 300 főnél nagyobb létszámú, nevelőotthoni funkción túl oktatást, szórakozást és mindennapi ellátást is biztosító gyermekvédelmi intézmények, melyek rendszerint 3 éves, vagy még fiatalabb kortól 18 vagy 24 éves korig fogadtak gyermekeket és ahol ebből adódóan a testvérek együttélése is megvalósulhatott. Ezek a gyermekvárosok falvak vagy városok, melyek az önellátás minden feltételével rendelkeznek. ${ }^{10}$ Elhatárolásuk a nyugati jogi kultúra gyermekköztársaságaitól azért is nehézkes, mert a gyermekvárosok történeti előzményének tekintenek ${ }^{11}$ két olyan hazai kezdeményezést, az ebesi Fiúkfalvát és Sz̨teblo Gábor Gaudiopolisát, melyek sokkal inkább gyermekköztársaságnak tekinthetők.

\section{Az amerikai előkép: Flanagen atya és a Fiúk Városa (Boys Town)}

Edward J. Flanagan (1886-1948) atya gyermekvédelmi modellje a veszélyeztett fiúk megmentésére és rehabilitására igazi úttörő kezdeményezés volt a 20. század elején az Amerikai Egyesült Államokban, amely a filmművészetnek is témát adott: munkájának híre a Boys Town című film (1938) sikerével és az atyát megformáló Spencer Tracy Oscar-díjával világszerte elterjedt.

Flanagan atya 1917-ben alapított otthont hajléktalan gyermekek számára. 1921-ben megvásárolta Omaha külvárosában az Overlook farmot, ahova kis közösségét is elhelyezte. A harmincas évekre fiúk százai éltek a faluban, ahol iskola, kollégiumok, igazgatási épületek és

\footnotetext{
${ }^{9}$ MAKAI, A háborús évek gyermekvédelmi-közösségi utópiái 94-104.

${ }^{10}$ CZIKE, Gyermekvárosok 1-13.

${ }^{11}$ CZIKE, Gyermekvárosok 3.
} 
egészségügyi létesítmény is múködött. A fiúk saját kormányzati szerveiket maguk választották meg. Lakásonként 20 fiú élt együtt. A lakás közössége elöljárót választott a közösség tagjai közül, aki a belső rendért, az újak eligazításáért, illetve a munkamegosztásért felelt. 6 hónaponként ezek közül az irányító, ellenőrző és többi fiú viselkedéséért felelős „,szobaparancsnokok” közül kerülhettek megválasztásra a Fiúk Városának tanácstagjai, akik aztán egy tanácstagot polgármesterré választottak. A gyermekköztársaság alulról építkező szervezetrendszere (elöljárók - tanács polgármester) a szintén választás útján hivatalba helyezett bírósággal egészült ki.

A veszélyeztetett gyermekek között végzett sok éves munkájából fakadóan Flanagen atya tudta, hogy semmiképp nem adhatja a fiatalok kezébe a nevelési feladatokat is; ezt a feladatot minden esetben felnőtt végezte. Az atya a háttérből irányította és ellenőrizte a gyermekköztársaság müködését, mintegy felügyeleti szervként. A választásokkal lehetőséget biztosított neveltjei számára, hogy megérezzék saját erkölcsi döntésük, magatartásuk súlyát ebben a miniatûr demokráciában. Az úgynevezett felnőtt tanácsadók szintén a gyermekek mellett álltak, és szükség esetén legfelsőbb fellebbviteli hatóságként jártak el, de törekedtek arra, hogy csak szélsőséges esetekben avatkozzanak be a neveltek életébe.

1936-ban a közösség hivatalos falu lett Nebraska államban. Flanagan atya fiainak otthona minden fiút befogadott származástól, hitvallástól vagy kulturális háttértől függetlenül. ${ }^{12}$ A pap minden gyermeknek újrakezdést kínált az életben, és mindent megtett, hogy felkutassa és magához vegye azokat a fiúkat is, akik adott esetben súlyos bủncselekmények miatt voltak börtönben. A világháború után Harry S. Truman elnök (1945. április 12. - 1953. január 20.) felkérte Flanagan atyát, hogy vigye az üzenetét, "Isten munkáját' a világ elé. Az atya külföldi utazásai során háborús árvákat látogatott meg, és tapasztalatairól beszámolva tanácsot adott kormányzati képviselóknek az otthonukat elhagyni kényszerült gyermekek gondozásáról. Példáját követve számos gyermekközösség jött létre Európában is.

Flanagan atya gyermekköztársaságának a különlegessége abban áll, hogy 1848-ban bekövetkezett halála után az eredeti elvekre építkezve, de folyamatosan továbbfejlesztették. Előbb Nicholas H. Wegner követte hivatalában, majd 1973-tól Robert P. Hupp atya, akinek a felügyelte alatt a Fiúk Városában két jelentős változás következett be: egyrészt az innovatív Családi Otthon Program felváltotta a kollégiumi rendszerú életet, másrészt lányokat is befogadtak a programba. A gyerekek tényleges otthonául szolgáló intézményben az úgynevezett család-tanárok olyan házaspárok voltak, akik a gyermekek neveléséről is gondoskodtak. A Fiúk Városa Nemzeti Kutatókórház 1977-ben nyilt meg, szintén Hupp hivatali ideje alatt. Ma a kórház országosan elismert kezelési központ hallás- és beszédzavarokkal küzdő gyermekek számára, és évente 60.000 siket és nagyothalló gyermeknek segít. Valentine J. Peter atya 1985 és 2005 között vezette a Fiúk Városát. Hivatali ideje alatt a Fiúk Városa több mint 12 helyszínre bővítette programjait és szolgáltatásait az Amerikai Egyesület Államok területén. A segítségben részesített gyermekek és családok száma az évtizedek alatt jelentősen megnőtt, mint ahogy az ellátás minősége is javult új, kutatáson alapuló szolgáltatások kifejlesztésével. A Fiúk Városa 1989-ben nyitotta meg nemzeti forródrótját. Napjainkban Steven E. Boes atya a gyermekköztársaság ügyvezető igazgatója. Országos gondozási hálózatuk központja Omahában marad. Az ország egyik legnagyobb nonprofit

12 WAGNER, Father Flanagan und seine Jungenstadt 136-140. 
gyermekgondozási ügynökségeként együttérző kezelést biztosítanak a gyermekek és a családok viselkedési, érzelmi és fizikai problémái esetében. A Fiúk Városa évente több mint 2 millió ember életében van jelen Amerika-szerte. A Fiúk Városa Nemzeti Forródrót megalapítása óta több mint 10 millió hívást intézett, a Fiúk Városa Nemzeti Kutatókórház pedig világszerte vezető szerepet játszik az Ushers-szindróma kutatásában. ${ }^{13}$

Vajon mi változott Néri Szent Fülöp utcagyerekeinek helyzete óta, akik a társadalmi oda nem figyelés következményeként lopásból, koldulásból, bűnözésből élő utcagyerek-hordákká válhattak, akiket mindenki csak megvet, kitaszít? Az Írországból származó Flanagan atya 1904-ben érkezett az Egyesült Államokba. Nyolc évvel később szentelték pappá. Szolgálatát Omaha Egyházmegyébe kezdte meg. Az atya tevékenységével és elképzeléseivel rövid idő alatt igazi társadalmi reformátorrá vált. Szenvedélyes felszólalásaival és fellépéseivel olyan társadalmi kérdésekre világított rá, amelyeket kevesen mertek addig megoldani. A 20. század elején a gyermekvédelem kezdetleges állapotban volt. Az atya mégis rendre kiállt a gyermekekért, felhívta a figyelmet arra, hogy a gyerekeknek joguk van a megbecsülésre, az élethez szükséges alapvető javakra és védelemre. ${ }^{14}$ Arra törekedett, hogy bezárják a javítóintézeteket és más fiatalkorúak számára létesített olyan intézményeket, melyekben a gyermekeket bántalmazták és nem egy esetben inkább rabként, mint védelemre szoruló személyként tartották. Flanagan atya kifejtette, hogy ezek a nevelési módszereik a gyermekek személyiségének épülését nem szolgálják. 1917-ben, miután évek óta együtt dolgozott Omaha hajléktalanjaival, figyelmét egyre inkább a veszélyeztetett fiúk felé fordította. Ilyen előzmények után, 1917 decemberében kölcsönkért 90 dollárjából kifizette a bérleti díját annak a panziónak, ahol otthont tudott adni védenceinek, és a következő tavaszra már 100 fiú lakott együtt Flanagan oltalma alatt. ${ }^{15} \mathrm{~A}$ modern ,irgalmas szamaritánus” őszinte példamutatása országszerte, sőt a határokon túl is támogatókat szerzett a gyermekvédelem ügyének, és az elesettek iránti társadalmi felelősségvállalásra buzdított.

\section{A gyermekköztársaságok európai példái}

Az „irgalmas szamaritánusok” sorát Európában Flanagen tevékenységével egyidőben a kvéker Karl Hermann Wilker (1885-1980) ${ }^{16}$ folytatta, bár a neveléstörténeti szakirodalom nem valódi gyermekköztársaságot, hanem inkább reformpedagógiát lát a kezdeményezésében. Wilker 1917. április 4-én vette át a Berlin-Lichtenbergi Kényszernevelési Intézet vezetését, amelyet egy humánus szemléletű gondozási intézménnyé alakított át a bentlakó gyermekek számára. Mindeközben Wilker sátortáborokat is szervezett szociáldemokrata gyermek- és ifjúsági szervezetek számára, és az evangélikus egyház önsegélyező programjával összeköttetésben álló kezdeményezés keretében úgynevezett békefalvakat hozott létre hajléktalanná vált fiatalok számára Nyugat-Németország több pontján is. ${ }^{17}$ A Lindenhof modellnek nevezett reformelképzelést Berlinben 1920-ban

\footnotetext{
13 Boys TOwn. Saving Children - Healing Families, https://www.boystown.org/about/ourhistory/Pages/default.aspx.

${ }^{14}$ OURSLER, Pater Flanagan von Boys Town 165.

15 LONNENBERG, Father Flanagan's legacy, passim.

16 BERNET, Deutsche Quäkerbibliographie 213-214.

17 ZIELINSKI, Über Selbstverwaltung als Erziehungsmittel in Heimen 46-48. és WILKER, Krisis der deutschen Fürsorgeerziehung 44-46.
} 
elöljáróival és munkatársai egy részével kibontakozó konfliktusa következtében kellett feladnia. ${ }^{18}$ 1922-ben Elisabeth Rotten segítségével megalapította a Nevelés Megújításáért Világszövetség (Weltbundes für Erneuerung der Erziehung) németnyelvű szekcióját, és sorra jelentek meg pedagógiai írásai. 1929 és 1930 között a szászországi Ottendorfban vezetett egy ifjúsági otthont (Jugenderholungsheims Ottendorf), majd a következő három évet Frankfurt am Mainban töltötte, ahol fiatal felnőttek és szabadságvesztésre ítéltek között végzett nevelő és képzési munkát, amit 1933ban a nemzetiszocialista rendszer elől történő emigrálása zárt le. ${ }^{19}$

Németország egyetlen valódi gyermekköztársasága a Starnberger tónál Johannes Zielinski vezetésével, a Boys Town példáját követve múködött, melyet 1947 elején alapítottak az amerikai katonai rehabilitációs kórház egyik épületében, a Buchbof-uradalom udvarházában 14 és 17 év közötti fiataloknak. Buchhof Ifjúsági Város (Jugendstadt Buchhof) 1947. május 27 -én nyitotta meg hivatalosan a kapuit. Háborúban megsérült, árvaságra jutott, vagy épp hajléktalanná vált fiúk voltak a lakók, akik a szállásért cserébe segítettek az ott állomásozó amerikai hadsereg bázisán. Egy idő után az amerikai hadsereg oberpfaffenhofeni repülőterének ifjúsági osztálya vette át a fiúközösség feletti gyámságot, amely nagyban hozzájárult az otthon kialakításához, szépítéséhez. Bár a neve nem maradt fenn, volt a patrónusok között egy amerikai őrmester, aki maga is Flanagan atya gyermekköztársaságának lakója volt egykor Nebraskában. Ổ a fiúkkal élt az otthonban a gyámságot gyakorló szerv kapcsolattartójaként, és ebben a pozícióban ő buzdította először arra a fiatalokat, hogy önkormányzatot alakítva igazgassák az otthont. Az önigazgatás fogalmát tehát nem a pedagógusok vezették be, és számukra ez nem volt foglalkoztatási kritérium, hanem az ismeretlen nevű őrmester kezdeményezésére épült ki. Johannes Zielinski 1948-ban vette át a gyermekköztársaság vezetését, akinek az irányítása alatt - bár korábban csak elméleti ismeretei voltak a gyermekköztársaságokról - kibontakozhatott az addig botladozó önkormányzatiság. Közgyúlést alapítottak, lett polgármesterük, megszervezték az oktatást és az intézmény gondnokságát is. ${ }^{20}$

A II. világháború és az azt követő évek bőven adtak lehetőséget a gyermekmentésre Európában máshol is. 1945 karácsonyának estéjén Lancianoban egy fiatal pap, Don Guido Visendaz 20 éhező, fagyoskodó fiút talált egy romos kaszárnyában. Élelmet és ruhát szerzett nekik, majd segített félig lakhatóvá tenni az épületet, megnyerve a fiúk bizalmát, akik amúgy nagyon tartózkodóak és bizalmatlanok voltak a felnőttek felé. A hajléktalan gyermekek száma a felújitási munkák alatt egyre nőtt. A pap javaslatára eldöntötték, hogy az épületekben megalapítják saját falujukat. Don Guido számos nemzetközi segítőszervezettel és magánszeméllyel, többek között Flanagen atyával is kapcsolatba lépett adományokat remélve, melyekből elsősorban a múhelyeiket fejlesztették. Volt varrodájuk, ahol katonai uniformisokat alakítottak át gyermekruhákká, cipészmúhelyben foltozták a hordhatatlanná vált lábbeliket, de ács- és kovácsmúhelyeket is múködtettek. 1948-ban azonban a rosszul felújított kaszárnyát visszavette az olasz állam, így a pap és a fiúk 15 éves polgármestere adománygyújtő körútra indult. Végül a haditengerészeti minisztérium biztosított számukra egy 2 kilométer hosszú adriai strandszakaszt Silvi Marinában, így az eddig igen kezdetleges körülmények között élő 130 fiú végre valódi ifjúsági falut

\footnotetext{
18 WILKER, Der Lindenhof. Werden und Wollen 92-95.

${ }^{19}$ FEIDEL-MERTZ, Karl Wilker 632-633.

${ }^{20}$ BABIC, Jungenstadt Buchhof 184-195.
} 
alapíthatott. ${ }^{21} \mathrm{Az}$ olasz állam ingyen szállította számukra a svájci építési alapanyagokat. A többnyire 14-20 évesekből álló fiúközösség egy egyedülálló építőszövetkezetet valósított meg. A fő kormányzati szervük a 7 tagú Fiúk Tanácsa volt, melyet a 130 fôs közgyúlés választott meg, ahogy ez a szerv döntött a polgármester, a bíró és a kincstárnok személyérôl is. ${ }^{22}$

Olaszország legismertebb gyermekköztársasága azonban a Cittá dei Ragazzi volt, amely Civitaveccia és Santa Marinella közötti tengerparti szakaszon helyezkedett el. A kezdeményezés egy szükséglakhatást biztosító római pincéből indult el, ahol utcagyerekeknek nyújtottak menedéket John Patrick Carroll-Abbing ír származású atya vezetésével, aki a pápa melletti, hosszabb ideig tartó szolgálata révén számos nemzetközi kapcsolatra tett szert. Ezeknek a kapcsolatoknak jó hasznát vette az utcagyerekek megsegítésében. 1944-ben alapított szervezete 180.000 utcagyereknek biztosított rendszeres étkezést és ruházkodást, melyet több ország segélyszervezeteivel karöltve tudtak megvalósítani Rómában. Alvási lehetôséget a város több, erre a célra kialakított pincéje nyújtottak, ahol képzésük biztosítására is törekedett Carroll-Abbing atya, a körülményeknek megfelelő formában. Miután ezek a pincék hamarosan szűkösnek bizonyultak, a romos tengerparti település, Tor Marangone elhagyott házaiban alapították meg városukat papjuk vezetésével a gyermekek, akik mindeközben a helyi iskolákat látogatták és a környező falvak múhelyeiben dolgozhattak. ${ }^{23}$ Az amerikai Fiúk Városához hasonlóan a mai napig múködik ez a kezdeményezés is.

A gyermekek önállóságának és személyes felelősségvállalásának fejlesztésére tett talán legmerészebb és legsikeresebb kísérlet a II. világháború alatt és után a Belgrád mellett múködő falu volt. A kevés fennmaradt feljegyzésből megállapítható, hogy egy nagy és ténylegesen önállóan múködő gyermekköztársaság volt ez az intézmény mintegy 2000 gyerekkel, hangsúlyosan elkülönítve a felnőttek világától. Ide tehát felnőtt nem léphetett be, és az államon kívül senki másnak nem tartoztak elszámolással. ${ }^{24}$ A közösség a heti rendszerességgel bejuttatott élelmiszeradományból élt, amelyet minden esetben maguk osztottak szét az egyes házak között. ${ }^{25}$ A gyerekek önállóan működtették a falu konyháját és minden közösségi helységet, beleértve a kertet is, amelyen minden ház együtt osztozott. Hetente írták meg a beosztást maguknak az elvégzendő munkákról, mint ahogy az iskolai teendőkről is. Az iskolául szolgáló helység egy nagy terem volt, ami egyúttal nappaliként és játszó szobaként is funkcionált. Minden vasárnap délelőtt gyűlést tartottak az összes ház lakóinak. Ilyenkor közösen megbeszélték az előző hét eseményeit, min változtatnának, mi volt jó, mi sikerült kevésbé szerencsésen. Ezeken az alkalmakon dönthettek választás útján a gyermekfalu ügyeiről, amit azonban meg kellett előznie a házankénti szavazásnak. Minden vasárnap tíz gyermeket választottak heti rendfelelősnek, akik a falu egészét ôrizték és felügyelték. Úgynevezett kultúr-küldötteik is voltak, akik az egyes múvészeti, kulturális programokért feleltek, és saját színjátszó csoportjuk volt, akik rendszeresen felléptek a közösség előtt. Saját pénzük nem volt, csak az ingóságaikért feleltek, az egymás közötti igazságos megosztásért és a rendeltetésszerű használatért. ${ }^{26}$

\footnotetext{
${ }^{21}$ ROTTEN, A Way of Life for War's Victims 8-10.

${ }^{22}$ HubER, Die „Cittá dei Ragazzi”. Eine selbstverwaltete Kinderstadt 18-23.

${ }^{23}$ Brosse, Homless Children 54-60.

${ }^{24}$ LENHARTZ, Das Selbsthilfewerk der Jugend 77-80

25 ZIELINSKI, Über Selbstverwaltung als Erziehungsmittel in Heimen 78.

${ }^{26}$ KAMP, Kinderrepubliken Geschichte 599-600.
} 
Az európai gyermekköztársaságok körében egyedi példa a ben shemeni dombokon elhelyezkedő falu az egykori palesztinai mandátumi területen. Az Európából őseik földjére vándorló vagy már ott született zsidó fiatalok önállóan végzett építô, pionír munkája nem csupán reformpedagógiai eszköz volt, hanem gazdasági szükséglet is. Az I. világháború utáni állapotok igen hasonlóak voltak Izraelben, mint Európában, a sok szenvedés után új világot kellett felépíteni, méghozzá meglehetősen sürgősen, és ez a jelenség az „ősújország” megszületése, 1948. május 14. után csak még inkább fokozódott. E múltbéli tapasztalat okán a mai napig nagy jelentősége van az izraeli iskolarendszerben az egyéni, önálló tevékenységnek és a munkára való nevelésnek. A gyakorlati, produktív fizikai munka a fiatalokban önbecsülést és a magas munkaerkölcsöt alakít ki, de fontos cél volt az is, hogy egy valóban új és igazságos társadalmat építsenek ki, amelyben közösségben élhetnek. A fiatalok nagyszámú bevándorlásával együtt ezek az elképzelések jó alapok voltak a gyermekköztársaságok kialakításához. ${ }^{27}$ A Ben Shemen Gyermek és Ifjúsági Falut (Kfar Hanoar Ben Shemen) alapítója, a német-izraeli Siegfried Lehmann már 1930-ban is konzekvensen gyermekköztársaságnak nevezte. Az alapításkor, három évvel korábban (1927) az orvos-pedagógus Lehmann 170 árva gyermekkel, köztük 3 és 17 év közötti fiúkkal és lányokkal indította el a falut. Pszichoanalitikus irányultsága is hozzájárult ahhoz, hogy nevelési stílusában kifejezetten a szeretetre, a szabadságra, az önrendelkezési jogra, valamint az ifjúság fokozatos önszerveződésére, illetve az erőszakmentességre és a türelemre helyezte a fókuszt.

A gyermekeket Ben Shemenben három korosztályi csoportra osztották. A 3 és 8 év közötti gyermekek két családi csoportban lettek elhelyezve külön lakásokban, a 9 és 14 év közöttiek úgynevezett gyerekközösségekben éltek, csoportonként huszonöt fő. Minden közösségnek saját háza, minden háznak egy „ház-anyája” és egy nevelője volt. A legmagasabb hatóság ennél a közösségnél a közgyúlés volt, ahol minden problémát megvitathattak és eldönthettek. Bíróságként is múködött, amely kis számban rótt csak ki büntetéseket. A múvészetnek, a zenének és a drámának nagyon nagy szerepe volt a gyerekek életében. Törekedtek arra, hogy ezeket a múvészeti ágakat minél vonzóbbá tegyék a gyerekeknek és fenntartsák az érdeklődésüket irányukba. Igyekeztek ezeket a mûvészeti foglalkozásokat a gyerekek érdeklődése szerint alakítani. A 15 és 18 év közötti korosztályból a lányok és a fiúk együtt éltek kommunaszerű közösségben, úgynevezett Kwuzabban. Házasként 25-40 fiatal helyeztek el nevelőikkel. Közösségi gazdálkodást folytattak a Lehmann által megvásárolt birtokon, de minden ház külön is gazdálkodott. Ennél a korosztálynál is a közgyülés volt a fő döntéshozó szerv, de kulturális és gazdasági kérdésekben külön tanácsok döntöttek, melyekben már felnőtt szakértők is helyet kaptak. A falu, amely 2017-ben fennállásának 90. évfordulóját ünnepelte, egykori öregdiákjait rendszeresen vendégül látja hazatérésük alkalmával, de sokan önkéntes a segítóévét is egykori otthonában dolgozza le. ${ }^{28}$

\section{Gaudiopolis, a magyar gyermekköztársaság}

A hazai gyermekköztársaságoknak két példáját tartják számon, melyek közül kifejlettebb és hatásában is erősebb Sztehlo Gábor Gaudiopolisa volt. Ennek ellenére említést kell tenni az 1943-

\footnotetext{
${ }^{27}$ KAMP, Kinderrepubliken Geschichte 602.

${ }^{28}$ LeHMANN, Eine jüdische Kinderrepublik in Palästina 73-79., LEHMAnN, Das Kinder- und Jugenddorf Ben Shemen 90-98.
} 
ban alapított ebesi Fiúkfalváról is, amely az amerikai Flanagen-modellt követve egy bentlakásos otthon volt az ebesi tanyavilágban a háborús évek nyomorában élő, debreceni árván maradt, csavargó gyerekek számára. A munka pozitív élménye, a közösség támogató ereje és a szeretet pedagógiája érvényesült itt. A mezőgazdasági munkát, ami élelmezésük alapját is szolgálta, a fiúk saját maguk szervezték meg. Az ,irgalmas szamaritánusok” a Keresztyén Ifjúsági Egyesület dolgozói, Pataki Gyula és Szekeeres Mibály voltak. Elképzelésük ${ }^{29}$ az volt, hogy a munka pozitív élménye vezeti vissza a gyermekeket a társadalomba, és a munkára való legnagyobb motivációt a szeretetük jelentette. Az otthon lakói, aki önként jelentkeztek, elfogadták annak szabályait, és maguk szervezték meg a megélhetésükhöz szükséges munkát. Az ebesi Fiúkfalva hanyatlásának oka az volt, hogy Szekeres Mibály 1944. június 22-én az életét vesztette abban a túzben, amely az otthonban keletkezett. Az újjáépítési kísérletek a tragédia után sikertelenek maradtak, és 1947-ben az újonnan létesült hajdúhadházi gyermekváros magába olvasztotta az apró intézményt. ${ }^{30}$

Egy hasonlóan elkötelezett ,irgalmas szamaritánushoz” kötődött a Gaudiopolis megalapítása is. A református egyház 1942-ben hozta létre a Jó Pásztor Bizottságot, amelynek eredeti célja a református vallású zsidó származású személyek lelki- és szociális gondozása volt. A bizottság tagjai látogatták a munkaszolgálatosokat, az internálótáborokat, árvaházat hoztak létre, menleveleket és keresztleveleket állítottak ki. Sztehlo Gábor, Sztehlo Kornél jogtudós evangélikus lelkész leszármazója közel 1600 gyermeket és 400 felnőttet mentett meg a nyilas rémuralom idején a biztos haláltól, vagyis Jó Pásztorként sokkal többet tett elvárt feladatánál: embert mentett. Miután megértette, hogy az egyházak sem tesznek igazán a zsidónak minősülő magyar állampolgárok gettósítása és bevagonírozása ellen, a Nemzetközi Vöröskereszt svájci képviselöje, Friedrich Born segítségével elkezdte a mentést. A német megszállását követően Pax nevű gyermekmentő akciójában néhány hét alatt harminckét otthont szervezett zsidó gyermekeknek, hogy megvédje őket az elhurcolástól, majd az ostrommal sújtott Budapesten 1944 karácsonyán egy nagy csapat gyerek budai villák pincéiben bujkált lelkész vezetőjükkel és más veszélyben lévő felnőttekkel együtt. A gyermekek túlnyomó többsége zsidó származású volt, akiket szüleik vagy más hozzátartozóik - ha akkor még egyáltalán életben voltak - a bátor papra bíztak. Karizmatikus, megnyugtató, hittel teli személyisége segített a gyerekeknek átvészelni a véres, félelmetes heteket. Esténként, amikor a mesének vége volt és a kicsik már aludtak, a nagyokkal egy új világ körvonalait kezdték el közösen kirajzolni, egy demokratikus gyerekköztársaságét. A folyamatos életveszélyben a túlélésüket jelentették ezek a „szellemi honfoglalások”, a látomások a pontos részletességgel megálmodott pince utáni közös életükről, az öröm köztársaságáról. ${ }^{31}$

Pedagógiatörténeti csoda született 1944-1945 fordulóján. Különböző életkorú gyerekeknek, köztük kamaszoknak nyújtott olyan reményt a lelkész, amelyben kapaszkodni lehetett a legsötétebb reménytelenség idején is, hogy lesz tovább és jó lesz. Még itt, ezekben a mostoha idôkben is keretet adott a folyamatos életveszélyben lévő, de amúgy is veszélyeztetett gyermekek életének azzal, hogy tudatosan szervezett napi program (torna, játék, tanulás, felolvasás, közös ének és ima) szerint mûködtek, mindez a gyermeki önellátásra, önkiszolgálásra épült. ${ }^{32}$ Életüket áthatotta

\footnotetext{
${ }^{29}$ PATAKI, „Sem erővel, sem hatalommal”. Nevelés a Fiúkfalván, passim.

30 VARGA, Fiúkfalva, CZINKE, Gyermekvárosok 1-13.

${ }^{31}$ Lásd hozzá TOLNAINÉ KASSAI Margit: Óvoda az óvóhelyen. Feljegyzések a Sztehlo-gyermekmentésről, passim.

${ }^{32}$ MAKAI, A háborús évek gyermekvédelmi-közösségi utópiái 94-104.
} 
az bizalom, a humanizmus és az önfeláldozó szeretet érzése egymás iránt. Sztehlo ebben a munkában nemcsak a legnehezebb sorsú gyermekekkel való bánásmód tapasztalatait szerezhette meg, hanem a múködő és fejlesztő közösségi élet kialakításáét is. Ugyanilyen fontos tapasztalatokat szerzett azzal kapcsolatosan, hogy milyennek is kell lenniük felnőtt segítőtársainak, ahhoz, hogy szervezettek és hatékonyak, de leginkább a gyerekek számára biztonságos otthont nyújthassanak.

A háború után az árvaházak hazánkban is megteltek, gyerekseregek kóboroltak az utakon és az ostrom alatt közösségé lett gyerekcsapatból sokaknak nem volt hova, kihez haza menni. Számukra Szteblo 1945-ben a Weiss Manfréd családja által felajánlott zugligeti villákban alapította meg a korábban megálmodott gyermekotthont, a Gaudiopolist, ahol közel nyolcszáz menekült gyerek élt.

Gaudiopolisban származástól és felekezettől függetlenül menedéket talált minden elhagyatott gyerek. A legkülönbözőbb társadalmi közegből érkeztek, legtöbbjük árva vagy félárva, zsidó származású volt. Voltak itt utcagyerekek, vagy olyan nem árva gyerekek, akiknek a szüleit politikai nézeteik miatt üldözték. Előfordult, hogy a szülők rossz kilátásaik miatt döntöttek úgy, hogy gyermekük az otthonban nagyobb biztonságban lenne. Nem volt az otthonban megkülönböztetés, de mindenkiről tudták, hogy honnan jött. Ez, a mindenféle tekintet nélküli életmentés volt az alapja a Gaudiopolisnak.

Az Örömváros egy nagyszabású pedagógiai kísérlet volt, amit akkor a szükség szült. Egymás tiszteletben tartását és a közösség fontosságának tudatosítását jelentette a gyermekek között, és ugyan így a felnőttek és a gyermekek között, ami akkoriban igazán újszerủ gondolkodásra vallott. Életük úgy lehetett teljes, ha az tudatosan egymásért, a közösségükért megélt élet volt. Így óvó és védő hátteret biztosított, akár egy igazi család. Három alappillére volt a rendszernek: első a család volt, aminek hiánya a gyerekek legnagyobb sérülését jelentette. Ezért úgy helyettesítették, hogy családnak neveztek minden egyes épületben, korosztály és nemek szerint elosztott csoportot. Sajátos neveik voltak a csoportoknak, például Farkastanya, Viperafészek, Hajnalcsillag. Minden családnak volt egy "édesanyja”, aki a nevelő volt. Hozzá lehetett fordulni minden ügyes-bajos dologgal, a gyerekek megbíztak bennük. A második pillér az iskola volt: Sztehlo igyekezett modern gondolkodású pedagógusokat, többek között az Eötvös-kollégium tanárait hívni az Örömvárosba. Egy-egy szabad asszociációs verselemzés segített a gyerekeknek megfogalmazni, kiadni az otthon hiányát, az emlékek feldolgozását, de szakmát is tanulhattak, melynek során neves szakemberek segítették a gyerekeket a gyakorlati ismeretek elsajátításában. A harmadik pillér a munka volt: mindenki eldönthette, hogy mit szeretne csinálni, könyvet kötni, lakatos, kőmúvesmunkát végezni, vagy épp kertészkedni. Ennek a közösségért végzett munkának az összetartó ereje kétségen kívülinek bizonyult. A gyerekeknek fontos volt megérteniük azt, hogy ha ma megsarkalnak egy cipőt, akkor holnap egy társuk el tud jutni az iskolába.

Az önkormányzatiságnak akkor van értelme, ha a tényleges problémák megoldására szerveződik. Sżteblo Gábor az otthon vezetésének mindennapi gondjait megosztotta a gyerekekkel. Teljes felelősséggel vettek részt az életük megszervezésében, sokszor az ő leleményük, vállalkozó szellemük oldotta meg az alapvető ellátás, forrásteremtés gondjait. Tüzelő szerzés, fakivágás, élelmezés, beszerzés, iskolaépítés, út- és sportpályaépítés, valamint a szórakoztatás, versenyek, játékok szervezése volt feladatuk. A kötelező jelzőt minden szinten kiiktatták, legyen szó hitről, 
munkáról, mégsem jött létre anarchia, hiszen a gyerekekben tudatosodott, hogy tőlük is függ a világuk működőképessége. Az önkormányzat önállóságot, önismeretet és ezzel önbizalmat adott tagjainak, olyan szabadságot, amely fegyelemmel, felelősséggel és bizalommal párosult. Megélhették az egyenrangúságot a felnőttekkel, és a hitet is abban, hogy hasznos tagjai a közösségnek.

A köztársaság élén Sztehlo Gábor volt a tiszteletbeli köztársasági elnök, de a miniszterelnök és a kormány tagjai gyerekek voltak. A lakóhelyekre, szobákra, házakra szerveződő elöljáróságok, a választott kormány, az alkotmány, a büntető törvénykönyv, néptribuni (ma ombudsmani) rendszer vagy a bíróság beleszólást, védelmet, demokratikus jogokat és kötelességeket fogalmazott meg. A viták - amelyek természetesen voltak - az igazság összetett voltát világították meg, soha nem egymás megsemmisítésére irányultak.

A munkavégzés feladata mindenkire kiterjedt, ami felelősséget és lehetőséget adott egyszerre. Pontos nyilvántartást az úgynevezett állampolgársági könyvben vezettek, amellyel pontokhoz, pénzhez (Gapo dollárhoz) juthattak a polgárok. A gyerekek nagyon komolyan vették a rájuk osztott szerepeket, mivel ez töltötte ki az életüket. Állampolgársági könyvükben célkitűzésként a következő szerepelt: „Kriszৃtus evangéliumának szellemében, társadalmi korlátokat megszüntetve, önálló, öntudatos, önismeretre és önbirálatra törekvö, gyakorlatilag ügyes, elméletileg képzett magyar embereket nevelni." Valódi toleranciát és szolidaritást élhettek meg a Gaudiopolis lakói, biztonságot és szeretetet, ami nélkül nem lehet egészségesen fejlődni. Az Örömvárosban teljes vallásszabadság uralkodott, miközben Sztehlo maga volt a hit, és minden cselekedetével bizonyságot is tett erről. Prédikált, de eközben gyakran hangoztatta, hogy „Aki nem his₹, az ne imádkozzék!!”. Tudta, hogy nem várható el a különböző gyökerekkel rendelkező gyerekektől az egységes vallásos áhitat. Ugyanakkor mindenkinek joga volt a saját titkaihoz, a szúkre szabott intim szférájához. A kapu kifelé is nyitva állt, elmehettek, ha nem tudtak együtt élni.

Kicsit olyan volt ez a közösség, mint egy farkasfalka: mivel voltak köztük olyanok, akiknek a szülei egymással harcoltak, vagy épp üldözték egymást, ennek a szülői örökségnek az okán kemény csaták is előfordultak, mivel azonban feltétlenül ki kellett jönniük egymással, megtanultak együtt élni és közremúködni. A közösség mindenkit helyre rakott, melyhez hasznosnak bizonyultak a gyermekek által alkotott törvények. Gaudiopolis jogszabályai segítettek, hogy rendet tartsanak a gyász, a düh és az általános kiábrándultság idején. Az intézmény az 1950-es államosításig lényegét tekintve önfenntartóan működött. A gyerekek gyümölcsöt termeltek, műhelyeik voltak, és a felnőttek minden elképzelhetô - nyugati - adományozót felkutattak, hogy támogatást szerezzenek a működéshez. Mindeközben semmilyen állami vagy egyházi támogatást nem kaptak csak, hiába kérvényezték azt, hanem csak a svájci Vöröskereszt juttatásait élvezhették. A „Gapo polgárok” visszaemlékezéseikben szinte kivétel nélkül arról számolnak be, hogy a közösségért érzett felelősséget vitték magukkal Gaudiopolisból: azt az élményt, hogy van értelme dolgozni, a közösségért felelősséget és munkát vállalni. A Gaudiopolis egykori zsidó lakója közül nem egy ismert lett a későbbi évtizedekben: életre szóló élményeket szerzett itt többek között Sárközi Mátyás író és Horváth Ádám rendező, mindketten Molnár Ferenc unokái, valamint Oláb György, a későbbi Nobel-dijas kémikus, Orbán Ottó költő vagy Szilágyi János riporter. ${ }^{33}$ Szteblo gyermekköztársasága egészen 1950 januári államosításáig múködött. A lelkész 1972-ben kapta meg a Világ igaza címet,

${ }^{33}$ MERÉNYI, Sztehlo Gábor, a gyermeknevelő 16-90. 
amelyet az izraeli Jad Vasem Intézet ítélt oda neki, mint nem zsidó származású embernek, aki a holokauszt idején élete kockáztatásával mentette az üldözötteket. Tevékenységének legfőbb támogatója mindvégig a svájci Vöröskereszt volt.

Hasonló kezdeményezés akadt még hazánkban is, bár az 1948-as rendszerváltást követően a gyermekvédelemnek ez a területe is átalakult. A pedagógus végzettségü Tildy Zoltánné Gyenis Eræsébet férje miniszterelnöki (1945. november 15. - 1946. február 1.), majd köztársasági elnöki (1946. február 1. - 1948. augusztus 3.) ciklusa idején aktív részt vállalt a háborús árvák támogatásában. 1948-ban a pilisi Beleznay-Nyáry kastélyban kezdte meg múködését Pax néven a leányotthon, amelynek felállítását Tildy Zoltánné kezdeményezte a református gyülekezeten keresztül.

Csillebérc története némileg kilóg a bemutatott köztársaságok közül, mert az eredeti elgondolás a politikai rendszerváltás miatt nem tudott megvalósulni. Az eredeti terv alapján Csillebérc olyan köztársaság lett volna, ahol a fő cél a játékos demokrácia tanulás. A csillebérci Úttörőváros (eredeti nevén Úttörők Köztársasága) és az Úttörővasút története elválaszthatatlan az 1946-ban létrehozott Úttörők Szövetségétől, amely kisdobosokból, úttörőkből és úttörővezetőkből, illetve pártoló tagokból állt. ${ }^{34}$

Hajdúhadházától nem messze, az erdő közepén, egy a háborúban megsemmisült katonai kiképző tábor maradványai között indította el első csoportját 1946-ban dr. Ádám Zsigmond pedagógus, pszichológus. ${ }^{35}$ Később nemzetközi segélyszervezetek támogatásával 300 gyermek számára nyújtott otthont a családi csoportos rendszerben múködött Hajdúhadházai Gyermekváros. A tanulás mellett nagyon jelentős szerep jutott a munkának a gyermekek életében, melyet a gyermekváros területén múködő számos múhelyben gyakorolhattak is. A gyermekváros belső intézményeit, felépítésének rendszerét a felnőttek a gyermekekkel közösen építették ki. A gyermekek szerepének hangsúlyosságát erôsítette, hogy a gyermekváros minden 10. életévet betöltött polgára szavazati joggal rendelkezett, élhetett jogával, melyet minden esetben titkos választás formájában valósítottak meg. Megválasztották a polgármesterüket, a rendőrkapitányt, a bírót, de a postást vagy az államtitkárokat is. A gyermekváros demokratikus rendszere és e rendszer működésének az elsajátítása a gyermekek között ellentétes volt azzal a közjogi struktúrával és politikai kultúrával, amit Magyarországon a negyvenes évek végétől a felnőtt társadalom kialakított. $^{36}$

\section{Mit üzen a múlt?}

A gyermekköztársaságok felállításának és múködésének tanulságaiból jól látható, hogy a traumát megélt, család nélkül levő gyermekek helyzetére, jövőjük építésére az úgynevezett képessé tétel (empowerment) módszerét használták a velük foglalkozók, a munka, a tanulás, a közösség megtartó erejének megtanításával. Család nélkül is kaphatták így muníciót ahhoz, hogy sorsuk jóra forduljon. Világosan látszik az is, hogy vannak olyan élethelyezetek, amikor nem elegendő a jogszabályok

\footnotetext{
${ }^{34}$ ERDEI, Csak látszólag utcakölykök, https:/ /artportal.hu/magazin/csak-latszolag-utcakolykok/.

35 ÁDÁM, Naplórészletek. Adalékok a Hajdúhadházi Gyermekváros megteremtéséhez és fejlődésének történetéhez $30-59$.

${ }^{36}$ BRosse, Homless Children 54.
} 
nyújtotta háló, hanem azok ismerete, gyakorlása és az empatikus helyzetkezelés, valamint a szakmai együttmúködés is fontos szempont a gyermekek legjobb védelme érdekében.

Tanulmányomban a második világégés és az azt követő időszakban kifejlődött gyermekvédelmi, közösségi reformkezdeményezések egy részét kívántam bemutatni, mindvégig azt a kérdést ismételve, hogy vajon a makro- és mikroközösségekben kialakult trauma következtében család nélkül maradt, szenvedéseket megélt gyermeknek milyen struktúrájú közösség a legmegfelelőbb a sikeres felnőtté váláshoz. Az ismertetett szerveződések múködésükkel egy közösségi típusú, demokratikus államot modelleztek. A hazai példáknak bizonyíthatóan neveléstörténeti gyökerei az egyes reformpedagógiákhoz, annak is leginkább szociális érzékenységű ágaihoz, a munkaiskolák tradícióihoz, a népfőiskolai mozgalomhoz is köthetôk. A bemutatott gyermekvédelmi kísérletek válsághelyzetben jöttek létre és erősítették fel az önkormányzatiságot. Szerkezeti felépítésük a gyermekek egész életét átfogta, az egyén, a közösség autonómiájának, a gyermek szabadságának, jogainak tiszteletére épülve próbálta visszaadni és megadni a gyermek biztonságát. Jogaikat és kötelezettségeiket gyakorló állampolgárokat neveltek. Sajnálatos, hogy az államosítás hazánkban ennek modellnek véget vetett. Tradícióik, hatásuk kimutatható volt a csillebérci Úttörő Köztársaság terveiben, a maga módján a Hajdúhadházi Gyermekváros müködésében is. Leghosszabb ideig Leveleki Esz̨ter vakációs állama, Pipecland maradt fenn. Beszüntették és el is hallgatták létezésüket, de némi nyomuk mégis maradt: Leveleki Esðter öröksége számos ma is létező nyaraltatással foglalkozó utódtáborban jelen van, valamint hatással volt az 1980-as évek elejétől kibontakozó úgynevezett iskolaköztársaságok keletkezésére, eszmerendszerére.

A mai magyar gyermekvédelemben a családmodell-típusú struktúrák vannak előtérben, kevéssé a fentebb ismertetett makrotársadalmat leképező modellek. ${ }^{37}$ A családi konfliktusok, az iskolai- és közösségi bántalmazások magas száma és még magasabb látenciája ismeretében, felmerül a kérdés, vajon nem lenne-e segítség a nagyobb jogtudatosság, önállóság, közösségi gondolkodás, munkamorál fejlesztésében a gyermekköztársaságok bizonyos pedagógiai elemeinek visszaemelése a nevelésbe, oktatásba?

Kérdés lehet, hogy létezik-e napjainkban olyan módszer, amely a mai társadalmi problémák (családi erőszak, fiatalkori bűnözés, különféle függőségek) esetén is sikeresen alkalmazható. Az 1980-as évektől múködik Finnországban, Helsinkitől 200 kilométerrel északra az erdő közepén egy gyermekköztársaság, melyet kifejezetten nehéz sorsú - fiatalkorú bủnelkövetők, drogfüggőséggel, magatartási zavarokkal küzdő - gyerekek számára hoztak létre. Vezetőjük Közép-Finnország egykori rendőrfőnöke, a jogász végzettségű Kalle Kari Björkmann és korábban óvónőként dolgozó felesége, Tukki. Családként élnek együtt több mint 30 fogadott gyermekükkel, és az erdő közepén épült faházaik ajtaja mindig nyitva áll. A „szülők” „gyermekeiket” fiamnak, lányomnak szólítják. Egyetlen fontos szabályuk, hogy nincsenek titkaik egymás elôtt. A házaspár törekszik a gyerekekkel közelséget, bizalmat kiépíteni, bennük az önbecsülést, az önbizalmat erősíteni. Olyan családias és szeretetteljes légkörben lehetnek itt a gyerekek, amit korábbi életükben nélkülözniük kellett. ${ }^{38} \mathrm{~A}$ tapasztalatok szerint az addig kezelhetetlennek nyilvánított gyerekek egy év leforgása alatt nagy átalakuláson mennek keresztül, és többnyire éretten, nyugodtan viselkedő fiatalokká válnak. Ebben

\footnotetext{
${ }^{37}$ MAKAI, A háborús évek gyermekvédelmi-közösségi utópiái 103.

38 ALANEN, Conceptualizing child-adult relations 129.
} 
a köztársaságban nem annyira az önkormányzaton van a hangsúly, hanem sokkal inkább a közgyúléseken, melyek a közös döntések meghozatalának helyszínei. A kuttulák száma egyre nő, további öt „család” alapításáról tudunk Finnországban, de vannak testvér közösségeik is Walesben, Nepálban és Írországban. ${ }^{39}$ Módszerüket az Európai Bizottság „példaértékűnek” nevezte. ${ }^{40}$

\section{Befejező gondolatok}

A 20. század első felének gazdasági és társadalmi válságai, kiváltképp a háborúk és a békekötések súlyos következményei rettenetes terhekkel növelték a gyermekek világának gondjait. A II. világháború évei mindezek után csak még inkább szétzilálták a gyermeksorsokat. A mérhetetlen fájdalom és a szenvedés tetőzéséből eredő lelki tisztulás szükségszerűen szülte meg a minőségileg új emberi kapcsolatokra épülő közösségeket, mint amilyen Magyarországon a Gaudiopolis, vagy épp a Fiúkfalva volt. Az ott élő gyermekek közösségi típusú, demokratikus felépítésű államot „játszottak”, éltek, tanultak. Válsághelyzetben jöttek létre ezek az intézmények: a háború okozta súlyos sebek talán épp az árván maradt gyermekeket nyomorította leginkább. Család nélkül, jövő nélkül maradtak volna ôk, ha nem hisznek bennük, tanítják őket, erôt sugároznak feléjük Szteblok és Patakik. Módszereikkel erősítették a jövő felnőtt társadalmát azzal, hogy képessé tették patronáltjaikat az életre. A képessé tétel (empowerment) nagy jelentőséggel bír a szociális tevékenységet folytató szakemberek pártfogoltjaikkal végzett munkájában is. ${ }^{41}$

Tanulmányom megírásának célja volt, hogy több példán keresztül bemutathassam a gyermekköztársaságokat, mint sajátos gyermekvédelmi kezdeményezéseket. Ma nem a világháborúval, hanem sokkal inkább az erôszak, a katasztrófák más formáival kell együtt élnünk egyénileg és közösségben egyaránt. Fontos, hogy mennyire képes úgy önállósodni, tanulni a ma gyermeke, aki egyben a jövő felnőtt generációjának tagja is, hogy a közössége aktív résztvevője legyen és másokkal is képes legyen jól együttmúködni. Igyekezzen tevékenységével éppúgy környezetét is építeni, mint ahogy saját céljait is elérni. A közel 24.000 magyarországi gyermekvédelmi gondoskodásban élő, ${ }^{42}$ kisebb-nagyobb mértékben eleve traumatizált gyermek nevelésében nagyobb szerepet lehetne és kellene adni azoknak a pedagógiai elveknek, gyermekvédelmi kezdeményezéseknek, melyek egykor épp azt az önállósodás lehetőségét adták meg a háborús árváknak. A létszámhiánnyal küzdő magyar gyermekvédelem neveltjeinek aligha képes megadni a megfelelő felkészítést a sikeres, önálló életkezdéshez. Lenne értelme talán az elmúlt 120 év gyermekvédelmi tapasztalatait leporolni és tudatosan egy részüket újra segítségül hívni.

\footnotetext{
${ }^{39}$ KAMP, Kinderrepubliken Geschichte 599.

40 SuPP, Monster im Ziegenstall 104-109.

${ }^{41}$ A képessé tétel úgy is definiálható, mint azok az eszközök (módszerek), melyek segítségével az egyének, a csoportok és/vagy a közösségek átveszik az irányítást saját életük felett, elérik saját céljaikat, ezáltal válnak képessé önmaguk és mások életkörülményeinek javítása érdekében munkálkodni. Lásd ADAMS, Social Work and Empowement 8. ${ }^{42}$ NÉMETH-ALMÁsI, Huszonnégyezer gyermek él jelenleg állami gondozásban hazánkban, https:// childhub.org/hu/gyermekvedelmi-hirek/magyarorszag-huszonnegyezer-gyermek-el-jelenleg-allamigondozasban-hazankban?language=hu.
} 


\section{Felhasznált irodalom}

Abrahamson, Lyn - Seligman, Y. - MARTin, E. - TeASDAle, John D.: Learned helplessness in humans: Critique and reformulation. Journal of Abnormal Psychology 1978/1. sz. 49-74.

DARLEY, John, M.: Bystander intervention in emergencies: Diffusion of responsibility. Journal of Personality and Social Psychology 1968/8. sz. 377-383.

ADAMS, Robert: Social Work and Empowement. London 2003

ÁDÁM Zsigmond: A nevelés elméletének és gyakorlatának kapcsolata a Gyermekvárosban. Magyar Pedagógia 1947/1. sz. 44-46.

ÁDÁM Zsigmond: Naplórészletek. Adalékok a Hajdúhadházi Gyermekváros megteremtéséhez és fejlődésének történetéhez. In: TÓTH László (szerk.): Emlékkötet Ádám Zsigmond gyermekvédő pedagógusról. Debrecen 1990, 30-59.

ALANEN, Leena - BERRY, Mayal: Conceptualizing child-adult relations. The future of childhood series. New York London 2001

Asch, S. E. Opinions and social pressure. In: HARE, A. P. - BOrGATtA, E. F. - BALES, R. F. (szerk.): Small groups: Studies in social interaction. New York 1966, 318-324.

BABIC, Bernhard: Jungenstadt Buchhof. In: Stadt Starnberg (szerk.): Gott zur Ehr', den Kindern zur Lehr'. 200 Jahre Schule in Starnberg. Starnberger Stadtgeschichte, 5. kötet. Starnberg 184-195.

BACCI, Pietro Giacomo: The life of Saint Philip Neri, apostle of Rome, and founder of the congregation of the oratory. London 1902, https://archive.org/details/lifeofphilipneri01baccuoft/page/n397/mode/2up (Letöltés: 2021. 08. 09.)

BERNET, Klaus: Deutsche Quäkerbibliographie. Vollständiges Schriftenverzeichnis des deutschen Quäkertums von den Anfängen um 1660 bis zur „religiösen Gesellschaft der Freunde” (Quäker) e.V. Nordhausen 2006

BERNET, Klaus: Quäker aus Politik, Wissenschaft und Kunst. Nordhausen 2008, 213-214.

BOYs TOWN. Saving Children - Healing Families, https://www.boystown.org/about/our-history/Pages/default.aspx (Letöltés: 2021. 08. 10.)

Brosse, Therese: Homless Children. Report of the Proceedings of the Conferece of Directors of Children's Communities in Trogen/Switzerland. Paris1950

CZIKE Klára, Gyermekvárosok. Educatio 1997/1. sz. 1-13.

DARLEY, J. M. - LATANÉ, B.: Bystander intervention in emergencies: Diffusion of responsibility. Journal of Personality and Social Psychology 1968/ 8. sz. 377-383.

DOMSZKY András: A gyermek és- ifjúságvédelem rendszere Magyarországon. In: CsÓKAY László - DOMSZKY András - HAZAi Vera - HerCzog Mária: A gyermekvédelem nemzetközi gyakorlata. Budapest 1994

EGERT Edith Eva: A döntés. Budapest 2017

EGERT Edith Eva: Az ajándék. 12 életmentő lecke. Budapest 2020

ERDEI Krisztina: Csak látszólag utcakölykök, https:/ /artportal.hu/magazin/csak-latszolag-utcakolykok/ (Letöltés: 2021. 08. 10.)

FEIDEL-MERTZ, Hildegard: Karl Wilker. In: MAIER, Hugo (szerk.): Who is who der Sozialen Arbeit. Freiburg 1998, 632-633.

GYÁNI Gábor: Gyermeksors a történelemben. Világosság 1980/7. sz.

GYŐRI György: Otthonteremtők. Köznevelés 1976/31. sz.

GYŐRI György: Az alkotó Gyermekváros. Köznevelés 1983/40. sz.

HANÁK Katalin: Társadalom és gyermekvédelem. Budapest 1978

Hiroto, Donald, S.: Locus of control and learned helplessness. Journal of Experimental Psychology 1974/2. sz. 187-193.

Huber, Gabrielle: Die „Cittá dei Ragazzi”. Eine selbstverwaltete Kinderstadt. Gmüder Hochschulreihe 10. Gmüd 1990

KAMP, Johannes-Martin: Kinderrepubliken Geschichte. Praxis und Theorie radikaler Selbstregierung in Kinder- und Jugendheimen. Wiesbaden 1995

KORALEK Lívia: A második világháború hatása a zsidó gyermek lelkivilágára. In: SPIEGEL Aladár (szerk.): A Tarbut 
Héber Kultúregyesuilet Iskoláinak Évkönyve az 1945-46-os tanévről. Budapest 1946

KOVÁCs Míra: Imakönyv és csipkés kombiné. Budapest 2009

KRASSÓ Sándor: Kötéltánc. Adalékok a pécsi zsidóság és Pécs 20. századi történetéhez. Pécs 2011

LAKATOS Kinga: A képessé tétel folyamata. Az érdekérvényesítés esélyeinek növelése a szociális és közösségi munkában. Budapest 2009

LANDESMAN György: Elöszó helyett. In: KERTÉSz Péter (szerk.): Árvaházi világtalálkozó. Budapest 1995

LEHMAnN, Siegfried: Eine jüdische Kinderrepublik in Palästina. Monatschrift für den Aufbau Palästinas 1930, 73-79.

LeHMAnN, Siegfried: Das Kinder- und Jugenddorf Ben Shemen. Das Werdende Zeitalter, 1929/2. sz. 90-98.

LENHARTZ, Rolf: Das Selbsthilfewerk der Jugend. Grundlagen. Ehrfahrungen und Aufgaben. In: Jahrbuch der Jugendarbeit. München 1949, 70-89.

LONNENBERG, B. - LYNCH, T. J. (szerk.): Father Flanagan’s legacy. Omaha 2003

MAKAI Éva: A háborús évek gyermekvédelmi-közösségi utópiái. Iskolakultúra 1996/2. sz. 94-104.

MERÉNYI Zsuzsanna: Sztehlo Gábor, a gyermeknevelő. Budapest 2009

NÉMETH-ALMÁsi Judit, Huszonnégyezer gyermek él jelenleg állami gondozásban hazánkban, https://childhub.org/hu/gyermekvedelmi-hirek/magyarorszag-huszonnegyezer-gyermek-el-jelenleg-allamigondozasban-hazankban?language=hu (Letöltés: 2021. 08. 10.)

OURSLER, Fulton: Pater Flanagan von Boys Town. Zürich 1951

PATAKi Gyula: „Sem erővel, sem hatalommal”. Nevelés a Fiúfalván. Mécses Keresztén Ifjúsági Egyesület. Budapest 1995

ROTTEN, Elisabeth Friderike: Children's Communities. A Way of Life for War's Victims. Paris 1954

SupP, Barbara: Monster im Ziegenstall. Der Spiegel. 1993. 07. 11., 104-109.

SzTEHLO Gábor: Isten kezében. Sztehlo Gábor Gyermek- és Ifjúságsegítő Alapítvány. Budapest 1994

TOLNAINÉ KASSAI Margit: Óvoda az óvóhelyen. Feljegyzések a Sztehlo-gyermekmentésről. Tények és tanúk. Budapest 2020

TÓTH László (szerk.): Emlékkötet Ádám Zsigmond gyermekvédő pedagógusról. Debrecen 1990

TRENCSÉNYI László (szerk.): Reformpedagógiai olvasókönyv. Budapest 1993

VARGA Domokos: Fiúkfalva. Budapest 1972

WAGNER, Georg: Father Flanagan und seine Jungenstadt. Schriftenreihe der Österreichischen Unesco-Kommision. Wien 1957

WILKER, Karl: Der Lindenhof. Werden und Wollen. Heilbronn am Neckar 1921

WILKER, Karl: Krisis der deutschen Fürsorgeerziehung. In: Schweizer Erziehungsrundschau. Zürich 1929, 44-46.

ZIELINSZKI, Johannes: Über Selbstverwaltung als Erziehungsmittel in Heimen für entwurzelte kriegsgeschädigte Jugendliche. München 1950 